\title{
Sustainable forest development: problems and prospects
}

\author{
Olga Ikonnikova \\ Head of Department of Accounting and Auditing \\ Northern (Arctic) Federal University named after M.V. \\ Lomonosov \\ Arkhangelsk, Russia \\ o.ikonnikova@narfu.ru
}

\author{
Aleksandr Gorkin \\ Associate Professor of Accounting and Audit Department \\ Northern (Arctic) Federal University named after M.V. \\ Lomonosoy \\ Arkhangelsk, Russia
}

\author{
Vitaliy Petrik \\ Head of Department of Landscape Architecture \\ Northern (Arctic) Federal University named after M.V. Lomonosov \\ Arkhangelsk, Russia
}

\begin{abstract}
Russia is the largest forest power in the world, it accounts for a quarter of the world's forest cover. Occupying almost half of the territory of the country, forests provide environmental safety and are one of the most important factors of socio-economic development. In modern conditions, the problems of conservation and use of forests are becoming more complex and require the modification of existing approaches to forest management, which should be implemented on the basis of the principles of sustainable development. State forest policy should be based on the recognition and respect of the rights of citizens to use forest resources and a favorable environment and multi-purpose and sustainable use of forests. The concept of sustainable development presupposes the consideration of economic, social and environmental factors that in the sphere of forest management means increasing the efficiency of the forestry sector, preserving the biosphere role of forests and increasing the level and quality of life of the population associated with forests. Despite the fact that a large number of normative documents in the field of forestry have been adopted in Russia, there are serious inconsistencies in them, as well as a considerable discrepancy between theory and practice. This study is aimed at identifying the main problems of sustainable forest management in Russia and identifying ways to overcome them, including using the experience of European countries. The authors believe that the long-declared approach to forest management based on the principles of sustainable development requires concrete steps both in the area of adjusting forest legislation, and in enhancing the legal awareness of Russian citizens, and their active involvement in the sphere of control over the turnover of forest products. An important factor is the improvement of the quality of life of the local population.
\end{abstract}

Keywords - sustainable development, forest management, management of forest resources.

\section{INTRODUCTION}

Achieving stable economic growth was one of the main goals of any state in the 20th century. The thoughtless striving at any cost to demonstrate to the world the growth of the gross domestic product, not supported by the introduction of new technologies and care for the environment, almost led to a global collapse. Suddenly it turned out that nature is not able to meet the growing needs of humankind.

In 1972, the Roman Club, an international public organization that made a significant contribution to the promotion of the idea of harmonization of human relations with nature, presented the famous "Limits of Growth" report, prepared by Donella and Dennis Meadows and their colleagues, which aroused enormous public resonance and for the first time so clearly and loudly denoted the problem of the critical state of the biosphere as a complete self-organizing system. Scientists were able to show that, while maintaining current trends in increasing production and the population of the planet, the limits of growth on Earth can be achieved in the near future. And although the scenarios of the development of the situation predicted by them were largely based on erroneous assumptions, the value of this report is unquestionable.

In 1972, the United Nations Conference on the Human Environment was held and the United Nations Environment Program was established, which indicated that the world community was already connected to the solution of this problem at the state level.

One of the first international documents that referred to the term "sustainable development" was the World Conservation Strategy, developed by the International Union for Conservation of Nature and Natural Resources, the UN Committee on the Environment and the World Wildlife Fund, which emphasized the need to take environmental factors into account Social and economic development.

In 1983, under the auspices of the United Nations, the World Commission on Environment and Development was established, headed by Gro Harlem Brundtland, whose name 
is now associated with the dominant interpretation of the term "sustainable development". In 1987, the Commission published the report "Our Common Future", in which sustainable development was defined as development, in which meeting the needs of the present generation does not undermine the ability of future generations to meet their own needs.

In 1992, the UN Conference in Rio de Janeiro adopted the Declaration on Environment and Development, one of the principles of which is to ensure equitable satisfaction of the needs of present and future generations. Central to the efforts to achieve sustainable development in accordance with the Declaration is the concern for people who have the right to a healthy and fruitful life in harmony with nature. An integral part of the development process should be the protection of the environment.

In 2002, at the World Summit on Sustainable Development held in South Africa, it was concluded that the world had not followed the path of sustainable development for two decades. The summit participants reaffirmed their commitment to Agenda 21 and the Declaration adopted in Rio de Janeiro, but the recommendations adopted at the summit, basically, remained on paper. Most environmental, economic, social and political problems continue to worsen. A similar conclusion was reached in 2012.

One should not think that the problems of environmental protection and the development of the principles of sustainable development were of concern only to foreign scientists. Back in 1964, a geographic edition of the Mysl Publishing House published a book by Soviet geographer and ecologist David L. Armand "To Us and Grandchildren," in which it was noted that "it is the moral duty of each generation to leave the next natural wealth in better condition and in greater quantity than It got from the previous one. "

One can say that the predecessor of the concept of sustainable development was the "concept of the noosphere", expressed by the Russian scientist V.I. Vernadsky, in which the noosphere is defined as the highest stage of the evolution of the biosphere, by which humanity is transformed into a new geological force, transforming the face of the planet with its thought and labor.

The concept of sustainable development unites three main components: economic, social and environmental. The economic component is based on the theory of the maximum flow of aggregate income; the social component focuses on preserving the stability of social and cultural systems, while the ecological component seeks to ensure the integrity of biological and physical natural systems.

Thus, sustainable development is possible only on the basis of harmony of relations among man, society and nature.

\section{MethodS}

The study was conducted on the basis of data from the Food and Agriculture Organization of the United Nations (FAO), statistics of the Federal State Statistics Service of Russia, materials of the Ministry of Natural Resources and
Ecology of Russia, as well as publications of Russian and foreign authors. Methods of logical and statistical analysis and questioning were used.

\section{DISCUSSIONS AND RESULTS}

In 2015, the UN General Assembly adopted 17 sustainable development goals, one of which concerns the rational use of forests.

Forests play an important role in the life of humankind. They cover some $30 \%$ of the world's land area (Keenan et al., 2015) and it is difficult to think of individuals that do not depend on forest products and services in some form on a regular basis. In addition, a large number of people depend on forests for at least part of their livelihood and well-being.

Forests play an important role in achieving the other 16 goals, including those related to poverty alleviation, food security, the promotion of sustainable agriculture and sustainable energy development.

As Kenneth G. MacDicken recalls, recognition that the production and protection functions of forests must be sustained by sound management practice is not new. From the earliest times, thoughtful people have encouraged the wise use of forests. Emperor Da Yu was the first Chinese emperor of the Xia Dynasty (21st century BC) to pay special attention to the sustainable management of natural resources and forests (Anonymous). In seventeenth century Europe, Evelyn (1664) and Colbert (1669 as reported in Brown, 1883) noted the negative influence of forest over-utilization on sustained provision of forest goods and services [1].

The reserves of forest resources both in the world and in our country are very solid; however inefficient forest management poses a serious threat for both ecological and socio-economic development of the territories. The challenge is to manage the forest's regenerative capacity in a way that produces benefits now without compromising future benefits and choices.

The area of forests and forest lands in the world is almost 4 billion hectares, in the official forestry sector more than 13 million people are employed, and three times more - in the informal sector. (FAO, 2014)

Forests are a renewable resource, but this does not mean that they do not require careful treatment. Sustainable forest management implies not only quantitative but also qualitative reproduction of forests, which should contribute to the conservation of biodiversity. When developing forest management strategies, preference should be given to those scenarios that cause the least damage to flora and fauna.

The restoration of forests is a long and complex process, which means that decisions regarding the use of forests that are being adopted now will affect the lives of not only current but also future generations.

The area of land covered by forest and trees is an important indicator of environmental condition [2].

The correct management of the reforested areas could improve many ecosystem services, such as: 
- Biodiversity conservation;

- Climate change mitigation and air quality improvement;

- Better management of water resources and their quality;

- Soil conservation;

- Timber and non-timber forests products;

- More occupation (especially environmental and forestryjobs);

- Recreational activities and tourism improvement;

- Easier people and materials circulation (after reduction of flooding and consequent road damages) [3].

Commitment to the principles of sustainable development is declared in most countries of the world. In 2015, Countries that had either policies and or legislation that support sustainable forest management cover $99 \%$ of global forest area (in $2010-70 \%$ ) [1].

However, it is not a secret that the basic principles embodied in programs, strategies, concepts, in practice, are not always a guide to action. In many respects, this is due to the fact that in the forest sector the interests of several groups of players that pursue completely opposite goals are facing.

Sustainable forest management (SFM) is a 'wicked' problem that is characterized by substantive goal conflicts and technical disputes [4]. This is as multiple forest policy actors from several levels of governance have competing understandings of SFM. These are driven by actors' values, beliefs, and interests. SFM understandings range from 'sustained yield' forestry (economic primacy of timber production) and 'multi-purpose forestry' (economic primacy of timber production and other ES) to 'ecosystem management' (primacy of biodiversity conservation), 'social forestry' (primacy of local communities' well-being), or 'carbon forestry' (primacy of climate mitigation and adaptation) [5].

For Russia, the rational management of forests is especially important, since it owns more than $20 \%$ of all forests of the Earth. The forest fund is state-owned, but market reforms and the opening of national borders since the early 1990s have brought new players into the sector, including private companies, non-governmental organizations (NGOs) and international consumer community. However, Russia has so far failed to introduce effective forest management [6].

The "Strategy for the Development of the Russian Federation Forestry for the Period to 2020" notes that the main problems of inefficient forest management in Russia are associated with insufficient accuracy in assessing the forest resource potential, poor control over the use of forests and inadequate forest management due to low technical level and shortage of staff. In the process of forest management Environmental and social objectives have been largely neglected.

One of the most acute problems of the forest industry in Russia is illegal logging, which accounts for more than $10 \%$ of all logging. This is especially true for the border regions of the country. At the same time, official statistics, as a rule, refer only to unauthorized logging, forgetting that the most damage to nature is caused by logging, which is carried out by lawful forest users, but with violation of existing rules (for example, cutting down the best trees under the guise of sanitary logging).

The damage from illegal deforestation exceeded 11 billion rubles in 2016. Over the past three years, according to the Ministry of Natural Resources and Ecology, the total damage amounted to 30.8 billion rubles, 52.4 thousand cases of illegal logging were recorded in total In 4.1 million cubic meters of wood.

The survey conducted by the authors of the survey among rural residents of three municipalities of the Arkhangelsk region showed that more than half of the respondents had at least once engaged in illegal logging. The main reason for this behavior was $70 \%$ of the lack of financial resources for the legal purchase of sawnwood or firewood, and $30 \%$ unnecessary bureaucratization of the process of obtaining legal rights to forest resources.

O. Ulybina and Sh. Fennell believe that one of the ways to overcome the crisis situation in the industry is forest certification.

Recently, countries have been passing laws helping to combat illegal logging by imposing stricter trade and labeling regulations and excluding illegally sourced timber and wood products from their markets, e.g. the US Lacey Act, 2008 (Section 8204) and Japan's Green Purchasing Policy, 2007. There is now also a European law (Regulation (EU) No 995/2010) banning the import of products containing illegally procured timber. Although most forest certification schemes are designed to verify timber legality, major programs also pursue a wider goal of establishing a certain standard of forest management.

Several forest certification schemes have emerged in Russia, of which the most widespread are two international non-governmental non-profit initiatives: the Forest Stewardship Council (FSC) and the Programme for the Endorsement of Forest Certification schemes (PEFC). Both schemes promote environmentally sustainable, socially responsible and economically viable forest management and certify different stages of timber production and procurement.

The process of certification is closely related to new, more environmentally-friendly logging technologies. Certification is generally expected to reduce the environmental impact of logging operations, engage companies in biodiversity conservation and improve socio-economic outcomes of their activity [7].

The situation with legal tenants of forest plots is also not quite safe - almost half of them do not pay taxes, rent payments, do not conduct fire prevention measures, do not engage in reforestation. Compulsory collection of taxes usually leads to bankruptcy of organizations whose founders later simply register a new legal entity and again become participants in the forest business. 
A serious problem is violations in the conduct of forest auctions - including in connection with the corruption component. Forest resources are transferred to use at minimal prices, which affects the revenue side of the state budget.

The consumer attitude to the forest, characteristic of Russian reality, is often explained by state ownership of forest land (and, as a consequence, by the absence of a diligent master). But the problems of nature management are not unique to Russia.

European countries have a long tradition of forest management and management, however, despite declaring the principles of sustainable development, there can also be a certain imbalance of interests of the parties involved in forest management.

It is very interesting to study the experience of forest management in countries whose natural and climatic conditions are quite similar to those in Russia, for example, in Finland.

Two thirds of Finland's land area is covered by boreal forests. The forest sector as a whole provides employment for 160,000 people. Finland is the third largest exporter of paper and paperboard in the world. A majority of the productive forests, $61 \%$, is owned by 685,000 private landholders (most of whom are families), while $24 \%$ is owned by the state and $9 \%$ by forest companies [8].

The overall goal of long-term Finnish forest policy has been the maintenance of forest productivity for economic returns that can support the Finnish economy and welfare system.

Donner-Amnell argues, however, that despite the environmentally-oriented changes in how policies were framed, the dominant pathway did not sincerely incorporate the three dimensions of sustainability, but rather continued to rely on a productivist logic. Finland was e.g. not a forerunner in international negotiations on environmental agreements such as climate issues in the fear that their participation would have adverse impacts on the competitiveness of the forest industry [9].

The different advocacy coalitions have remained distinct to this day, and their relations continue to be polarized. The coalitions disagree on the process for defining forest policy goals; the Forestry coalition wants landholders and the industry to maintain decision-making authority over forest policies, whereas the Environmental coalition calls for all actors to have an equal chance to participate in and influence decisions. In between these coalitions is an "Administrative coalition" that sees the fulfilment of different forest-related goals as the main sustainability challenge in forestry, and maintains that opinions from outside "the sector" are also welcome [10].

M. Kröger, R. Raitio believe that biodiversity and other environmental issues, although mentioned, clearly stand in a secondary position in the implementation of the policies, and this hierarchy of goals has become more evident after 2010 . Productivism rather than a genuine balance seeking between the three dimensions of sustainability characterises Finnish forest policy [11].

Although it should be noted that there are also many forest owners who are aware of the importance of the ecological and social components of sustainable development. For instance, a recent study by Hayrinen [12] found that in Finland there are certain forest owner groups, especially among female, highly educated and urban forest owners, who value aesthetic and forest conservation objectives more than industrial raw material production.

Multiple uses of forests are highlighted as the conservational, recreational and spiritual values of forest have increasingly become part of the current sustainable forest management paradigm $[13,14]$.

\section{CONCLUSION}

The authors believe that the following activities will contribute to the sustainable development of forests:

1) Enhancement of penalties for illegal logging and other violations of forest legislation. This measure is difficult to consider progressive, but, as practice shows, it can be very effective.

Many believe that the way out from the current situation may be the transfer of forests into private ownership, but such step can have serious negative consequences, including social ones.

2) Improving the effectiveness of forest management (including reforestation) both from the state and from public organizations and individuals. Effective control allows one not only to quickly identify violations of legislation, but also to prevent them.

It seems reasonable to involve local residents in the process of forest management. At present, unfortunately, local community is considered as the least significant stakeholder in the process of decision making and forest resource management.

Abrar Juhar Mohammed, Makoto Inoue believe that the involvement of non-forest harvesting organizations in making rules that are related to dispute resolution and benefit sharing should be promoted [15].

At the same time, non-state actors recognise their inability - due to limited resources, authority and legitimacy in the eyes of other stakeholders and wider population - to fully replace the state in law enforcement and forest control, meaning unsustainability of their efforts in the long run, and calling for more active and consistent cross-sectoral cooperation. The role of the state, whose involvement even in its current shape noticeably accelerates change, is vital for non-state initiatives. The limitations of non-state-driven change can only be overcome by a reformed and wellfunctioning state, which will ensure greater competition, access to accurate information and welcome innovation [16].

3) Raising the level and quality of life of the rural population. As already noted, it is economic problems that often push local residents to violate legislation. 
In Russia, the average wages of those employed in forestry and agriculture have been 1.5-2 times lower for a long time than the average for the economy. In rural areas, infrastructure is poorly developed, access to medical and social services is difficult. All this can not but affect the behavior of the inhabitants of rural areas. It is the forest industries (both legal and illegal) that are the source of additional earnings for the majority of the villagers. And the state should help them develop precisely within the legal framework.

\section{4) Expanding the integrated use of forests.}

Unfortunately, over many decades, the development of natural resources has been extensive, and the use of forest resources has been mainly directed towards obtaining wood. Sustainable development requires a more complete and efficient use of both by-products of the forest and sawmill production waste.

One should remember about the recreational function of forests. Forests are a traditional place of recreation for a person, and it is important to instill in citizens from the childhood an orientation toward a careful attitude to nature. As practice shows, a significant part of forest fires, as a result of which colossal damage to forest ecosystems is caused, arises from the impact of anthropogenic factors.

Undoubtedly, multifunctional use of forests can lead to intensification of conflicts between different parties involved in forest management (tenants, local population, ecologists), and the task of state and municipal authorities is to find a compromise that will maximally combine economic efficiency with social justice and environmental safety.

In any case, sustainable forest development is possible only if the interests of society as a whole prevail over the interests of individual businesspersons, the industry and even the state.

\section{Acknowledgment}

The study was carried out with the financial support of the Russian Foundation for Basic Research and the Government of Arkhangelsk Region within the framework of scientific project No. 16-12-29003 "The Economic Substantiation of the Restoration of Gum Preparation in Industrial Pumping in the Context of Ensuring Sustainable Forest Development in Arkhangelsk Region"

\section{References}

[1] K.G. MacDicken, Ph. Sola, J.E. Hall, C. Sabogal, M. Tadoum, C. de Wasseige. Global progress toward sustainable forest management, Forest Ecology and Management, vol. 352, pp. 47-56, 2015.

[2] R. Keenan, G. Reams, J. Freitas, E. Lindquist, F. Achard, A. Grainger, 2015. Dynamics of global forest area: results from the 2015 Global Forest Resources Assessment. Forest Ecol. Manage, vol. 352, pp. 9-20, 2015.

[3] V. Coletta, F. Lombardi, V. Altieri, G. Bombino, C.Marciand, G. Menguzzato, P.A. Marziliano. Environmental resources conservation through sustainable forest management. Social and Behavioral Sciences vol. 223, pp. 758-763, 2016.

[4] S. Wang. 2002.Wicked problems and metaforestry: is the era of management over? The Forestry Chronicle, 78 (4), pp. 505-51, 20020.

[5] M. Sotirov, M. Blum, S. Storch, F. Selter, U. Schraml. Do forest policy actors learn through forward-thinking? Conflict and cooperation relating to the past, present and futures of sustainable forest management in Germany. Forest Policy and Economics - Available online 28 November 2016 http://www.sciencedirect.com/science/article/pii/S1389934116304270

[6] Materials of NGOs for Development of National Forest Policy of The Russian Federation. In: Shvarts, E.A., Kulikova, E.G., Shmatkov, N.M., Kopylova, E.B. (Eds.), 2012, WWF, Moscow.

[7] O. Ulybina, Sh. Fennell. Forest certification in Russia: Challenges of institutional development. Ecological Economics 95, pp. 178-18, 20137.

[8] Finnish Statistical Yearbook of Forestry, 2014. Official statistics of Finland. Finnish Forest Research Institute, Vantaa.

[9] J. Donner-Amnell, Suomen metsäteollisuuden muodonmuutos? (Transformation of the Finnish forest industry? Alue ja ympäristö. 292, pp. 4-22, 2000.

[10] T. Harrinkari, P. Katila, H. Karppinen. Stakeholder coalitions in forest politics: revision of Finnish Forest Act. Forest Policy and Economics67, pp. 30-37, 2016,.

[11] M. Kröger, R. Raitio. Finnish forest policy in the era of bioeconomy: A pathway to sustainability? Forest Policy and Economics, Volume 77, pp. 6-15, April 2017.

[12] L. Häyrinen, O. Mattila, S. Berghäll, A. Toppinen, Forest owners' sociodemographic characteristics as predictors of customer value: evidence from Finland. Small Scale For. 14 (1), pp. 19-37, 2015.

[13] G. Richnau, P. Angelstam, S. Valasiuk, L. Zahvoyska, R. Axelsson, M. Elbakidze, J. Farley, I. Jönsson, I. Soloviy, Multifaceted value profiles of Forest owner categories in South Sweden: the River Helge a catchment as a case study, Ambio 42 (2), pp. 188-200, 2013.

[14] L. Häyrinen, O. Mattila, S. Berghäll, A. Toppinen, 2016. Lifestyle of health and sustainability of forest owners as an indicator of multiple use of forests. Forest Policy and Economics, Volume 67, Pages 10-19, June 2016.

[15] A.J. Mohammed, M. Inoue. Identifying salient forest SES attributes for sustainability: Amulti-country study. Land Use Policy, 60, pp. 197-205, 2017.

[16] O. Ulybina. Interaction, cooperation and governance in the Russian forest sector. Journal of Rural Studies, Volume 34, pp. 246-253, April 2014. 